\title{
Gemeinschaft City: Konsep dan Pengukuran Kota Guyub
}

\author{
Karina Pradinie Tucunan dan Yennita Hana Ridwan \\ Departemen Perencanaan Wilayah dan Kota, Fakultas Arsitektur, Desain, dan Perencanaan \\ Institut Teknologi Sepuluh Nopember \\ e-mail: karina.haricahyono@gmail.com
}

\begin{abstract}
Abstrak - Dalam dialog keruangan dan model perkembangan perkotaan, kampung merupakan representasi dari sistem guyub dan tidak akan ditemui dalam konteks perkotaan. Paradigma planning sendiri bergeser dari yang semula berorientasi top down menjadi bottom up. Tujuan perencanaan ini untuk menciptakan lingkungan yang lebih "guyub" (gemeinschaft) untuk masyarakat dimana masyarakat bisa menikmati hasil perencanaan itu sendiri. Keberadaan kota yang guyub dimana masyarakatnya memiliki inisiatif dalam pembangunan kotanya dan termasuk berpartisipasi di dalamnya memiliki dampak yang lebih positif terhadap pembangunan kota. Kota guyub (gemeinschaft city) timbul disebabkan dua konsep besar yakni Tonnies (1886) dengan faktor - faktor dominasi nilai - nilai kekerarabatan dibandingkan dengan nilai-nilai yang sifatnya formal pada suatu wilayah dan perkembangan paradigma perencanaan di Amerika yang diusung Jane Jacobs (1992) yang menunjukkan bahwa perencanaan berbasis komunitas merupakan jenis perencanaan terbaik yang dapat dihasilkan oleh seorang perencana. Konsep mengenai gemeinschaft dan community based planning memang merupakan dua konsep yang berbeda, namun konsep ini secara tidak langsung memiliki keterkaitan yang erat satu sama lain. Melihat dua hal tersebut maka dapat ditarik suatu dugaan bahwa Kota Guyub merupakan kota atau area/bagian perkotaan yang memiliki karakter lokal dan nilai-nilai gemeinschaft yang diindikasikan oleh hubungan/interaksi kekerabatan yang ada di wilayah tersebut dan terwujud dalam ekspresi keruangan yang intim dengan masyarakatnya. Dengan definisi yang sangat baru tersebut maka diperlukan indikator dan parameter untuk membuktikan keberadaan Kota Guyub. Setidaknya terdapat tiga aspek untuk dapat membedakan bentukan Kota Guyub dan Kota formal yaitu bentuk dasar, underlying system dan ekspresi keruangan yang ditimbulkan.
\end{abstract}

Kata Kunci-Community Based Planning, Gemeinschaft city, Kota Guyub

\section{PENDAHULUAN}

$\mathrm{P}$ erkembangan kota - kota di Indonesia dan di dunia memiliki pola yang berbeda, namun secara umum karakteristik di Asia Tenggara hampir memiliki kesamaan yakni dengan memiliki kampung sebagai salah satu bentuk permukiman yang spesifik dan banyak dikaji oleh antropologist dunia. Dalam fenomena sosiologi (konteks perkotaan), hipotesis Tonnies (1887) bahwa setiap kota akan membentuk sistem yang formal (gesselschaft) dibandingkan dengan sistem yang kekeluargaan / guyub (gemeinschaft). Dalam dialog keruangan dan model perkembangan perkotaan, kampung merupakan representasi dari sistem guyub yang diprediksi oleh Tonnies (1887) tidak akan ditemui dalam konteks perkotaan.

Tidak hanya dalam konteks sosiologis dalam membahas mengenai paradoks yang terjadi dalam Kota Guyub dengan kampung sebagai pusat pembahasan. Paradigma planning sendiri bergeser dari yang semula berorientasi top down menjadi bottom up di Amerika setelah kasus yang diangkat Jacobs (1992) dalam North End. Tujuan perencanaan ini untuk menciptakan lingkungan yang lebih "guyub" (gemeinschaft) untuk masyarakat dimana masyarakat bisa menikmati hasil perencanaan itu sendiri. Jacobs (1992) dalam konteks North End menyatakan bahwa dengan keberadaan kota yang guyub atau dalam sebuah terminologi dimana masyarakatnya memiliki inisiatif dalam pembangunan kotanya dan termasuk berpartisipasi di dalamnya memiliki dampak yang lebih positif seperti tingkat kesehatan yang lebih tinggi, tingkat kriminalitas yang lebih rendah dan juga kawasan yang lebih livable dibandingkan dengan kawasan lain. Paradigma perencanaan yang diusung Jacobs (1992) adalah perencanaan berbasis komunitas, yang pada perkembangannya dipercaya memiliki sistem yang lebih baik dalam: 1). menjembatani antara hal yang teknis dan yang abstrak (Al Kodmani, 2001), 2). sebagai suatu sumber dari perubahan entitas politik (Grengs, 2002), 3). Pendekatan yang lebih baik dalam pengentasan kemiskinan (Mason, 2008) dan 4). alat yang lebih baik untuk meningkatkan kualitas hidup masyarakat (Walker, 2001).

Jenis perencanaan dan kondisi masyarakat yang guyub, lebih lanjut dapat merupakan sebuah keuntungan bagi kota kota di Indonesia dalam perencanaan ke depan, dimana isu mengenai tingkat penerapan produk perencanaan yang aplikatif di kota - kota di Indonesia masih sangat rendah. Penelitian mengenai Kota Guyub dan hasilnya dapat menjadi payung dan acuan ke depan bagaimana seharusnya perencanaan diusung untuk dimasa mendatang di Indonesia.

Pertanyaan penelitian yang ingin dijawab dalam makalah ini adalah:

1. Apakah itu Kota Guyub dan bagaimana posisinya dalam dialog kota dan juga perencanaan?

2. Bagaimanakah mengukur keguyuban sebuah kota/bagian kota?

\section{METODE PENELITIAN}

\section{A. Pendekatan dan Jenis Penelitian}

Metodologi yang digunakan dalam mendefinisikan konsep dan mengukur bagaimana Kota Guyub ini menggunakan 
pendekatan rasionalistik dengan menghasilkan kerangka teoritik terhadap konsep mengenai Kota Guyub.

Tabel 1.

Metodologi yang Digunakan dalam Penelitian

\begin{tabular}{|c|c|}
\hline Pendekatan Kualitatif & 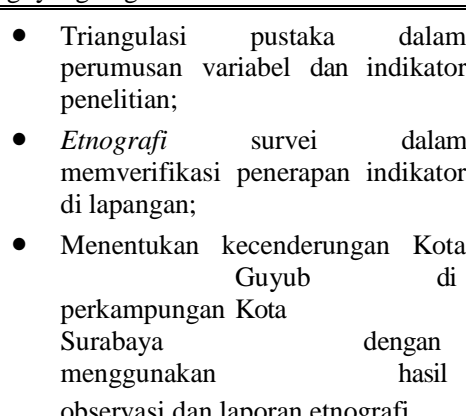 \\
\hline $\begin{array}{l}\text { Pendekatan } \\
\text { Kuantitatif }\end{array}$ & $\begin{array}{l}\text { - Analytical Hierarchical Process } \\
\text { (AHP) dalam menentukan bobot } \\
\text { variabel yang digunakan untuk } \\
\text { pengukuran pada lapangan; } \\
\text { - Melakukan perhitungan / klasifikasi } \\
\text { untuk masyarakat Kota Guyub } \\
\text { rendah / tinggi. }\end{array}$ \\
\hline
\end{tabular}

\section{B. Metode Pengumpulan Data dan Analisis}

Tahapan selanjutnya adalah memverifikasi indikator indikator yang terkait dengan Kota Guyub beserta bobotnya dengan menggunakan Analytical Hierarchical Process (AHP). Proses ini dapat dilihat pada tabel 2.

a. Penerapan Etnografi Survey

Dalam studi pustaka yang telah ditriangulasikan ditemukan variabel - variabel yang terkait dengan pola gemeinschaft city, namun indikator tersebut memiliki kemungkinan tidak sama antara yang ada di lapangan, sehingga verifikasi dilakukan di beberapa kampung yang ada di Kota Surabaya. Pemilihan Kampung dilakukan secara purposive dengan mengedepankan intensity sampling (2000) dengan mempertimbangkan alasan: sebaran lokasi, heterogenitas/homogenitas, permukiman lama atau perkembangan baru dan kedekatan dengan lokasi pertumbuhan. Bagian wilayah yang tidak disertakan pada daftar sampel tersebut adalah wilayah Surabaya Barat, hal ini disebabkan oleh karakteristik Surabaya Barat yang memiliki kecenderungan pertumbuhan perumahan formal (one gate system) yang dikembangkan oleh developer dibandingkan dengan kampung - kampung yang tumbuh secara organik.

Tabel 2.

Intensity Sampling dalam Penerapan Sampel Purposive pada Penelitian

\section{Studi Kasus} yang dipilih

\begin{tabular}{|c|c|}
\hline $\begin{array}{l}\text { Kampung } \\
\text { Keputih dan } \\
\text { sekitarnya }\end{array}$ & $\begin{array}{l}\text { - } \begin{array}{l}\text { Perkembangan dari permukiman baru } \\
\text { (setelah perkembangan merembet ke }\end{array} \\
\text { Surabaya Selatan); } \\
\text { - } \quad \begin{array}{l}\text { Dekat dengan kutub pertumbuhan } \\
\text { (kampus ITS); }\end{array} \\
\text { - } \quad \text { Heterogenitas etnis; } \\
\text { - } \begin{array}{l}\text { Masih berupa pola pertumbuhan } \\
\text { perkampungan; }\end{array} \\
\text { - Terletak di Surabaya Timur. }\end{array}$ \\
\hline $\begin{array}{l}\text { Kampung } \\
\text { Sidosermo }\end{array}$ & $\begin{array}{l}\text { - } \quad \text { Perkembangan dari permukiman baru; } \\
\text { - Heterogenitas etnis dengan dominasi } \\
\text { Etnis Jawa; } \\
\text { - Masih berupa pola pertumbuhan } \\
\text { - } \quad \text { Terkampungan; } \\
\text { - }\end{array}$ \\
\hline $\begin{array}{l}\text { Kampung } \\
\text { Arab } \\
\text { (Ampel) }\end{array}$ & $\begin{array}{ll}\text { - } & \text { Perkembangan dari permukiman } \\
& \text { lama; } \\
\text { - } & \text { Homogenitas etnis; } \\
\text { - } & \text { Masih berupa pola pertumbuhan } \\
\text { - } & \text { Terkampungan; } \\
\text { - } & \text { retak di Surabaya Utara. }\end{array}$ \\
\hline $\begin{array}{l}\text { Kampung } \\
\text { Madura } \\
\text { (Sencaki) }\end{array}$ & $\begin{array}{ll}\text { - } & \text { Perkembangan dari permukiman lama; } \\
\text { - } & \text { Homogenitas etnis; } \\
\text { - } & \text { Masih berupa } \\
\text { - } & \text { pertumbuhan perkampungan; } \\
\text { Terletak di Surabaya Utara. }\end{array}$ \\
\hline
\end{tabular}

b. Proses AHP

Proses AHP yang dilakukan dalam penelitian ini melibatkan lima pakar yang terdiri atas panel ahli sebagaimana berikut dalam tabel 3 .

Tabel 3.

Kredibilitas dan Bidang Kepakaran Narasumber yang Digunakan dalam Penelitian

\begin{tabular}{|c|c|}
\hline Panel 1 & $\begin{array}{l}\text { Ekspertise (Keahlian) } \\
\end{array}$ \\
\hline Narasumber 1 & $\begin{array}{l}\text { - Ahli di bidang perencanaan kota } \\
\text { - Lebih dari } 15 \text { tahun berpengalaman dalam } \\
\text { proses perencanaan dan berkolaborasi } \\
\text { dengan pemerintah dalam menyusun } \\
\text { dokumen perencanaan baik partisipatif } \\
\text { maupun konvensional }\end{array}$ \\
\hline Narasumber 2 & $\begin{array}{l}\text { - } \text { Ahli di bidang Sosiologi } \\
\text { - Lebih dari } 15 \text { tahun berpengalaman } \\
\text { menyusun penelitian-penelitian bertema } \\
\text { sosiologis termasuk dinamika masyarakat }\end{array}$ \\
\hline Narasumber 3 & $\begin{array}{l}\text { - Ahli di bidang Sosiologi Perkotaan } \\
\text { - Lebih dari } 10 \text { tahun berpengalaman } \\
\text { menyusun penelitian-penelitian bertema } \\
\text { sosiologi } \\
\text { - Berpengalaman dalam riset sosiologis skala } \\
\text { internasional }\end{array}$ \\
\hline Narasumber 4 & $\begin{array}{l}\text { - } \text { Ahli di bidang Perumahan dan Permukiman } \\
\text { - Lebihdari } 15 \text { tahun berpengalaman } \\
\text { menyusun penelitian-penelitian bertema } \\
\text { perumahan dan permukiman terutama di } \\
\text { sekitar kampung pesisir }\end{array}$ \\
\hline Narasumber 5 & $\begin{array}{l}\text { - Ahli di bidang sanitasi berbasis masyarakat } \\
\text { - Lebih dari } 15 \text { tahun berpengalaman } \\
\text { mengabdi dan menerapkan perencanaan } \\
\text { kolaboratif dengan masyarakat, terutama } \\
\text { pada bidang sanitasi }\end{array}$ \\
\hline
\end{tabular}




\section{HASIL DAN PEMBAHASAN}

\section{A. Konsepsi Kota Guyub (Gemeinschaft City)}

Kota guyub (gemeinschaft city) yang dikonsepkan oleh penulis merupakan sebuah bentuk kota yang timbul disebabkan dua konsep besar yakni Tonnies dan Jacobs, Tonnies (1886) dengan faktor - faktor dominasi nilai - nilai kekerabatan dibandingkan dengan nilai - nilai yang sifatnya formal pada suatu wilayah dan perkembangan paradigma perencanaan di Amerika yang diusung Jane Jacobs (1992) menunjukkan bahwa perencanaan berbasis komunitas merupakan jenis perencanaan terbaik yang dapat dihasilkan oleh seorang perencana.

Konsep mengenai gemeinschaft dan community based planning memang merupakan dua konsep yang berbeda, namun konsep ini secara tidak langsung memiliki keterkaitan yang erat antara satu dengan lainnya, yang dapat dilihat pada Tabel 4 sebagai berikut.

Tabel 4.

Komparasi Konsep Gemeinschaft City dengan Gesselschaft City

\begin{tabular}{|c|c|c|}
\hline Konsepsi & Gemeinschaft City & Gesselschaft City \\
\hline $\begin{array}{l}\text { Orientasi } \\
\text { perkembangan }\end{array}$ & $\begin{array}{l}\text { Organic (kota tumbuh } \\
\text { secara alami dimana } \\
\text { masyarakat memiliki } \\
\text { kebebasan dalam } \\
\text { merencanakan ruang } \\
\text { kotanya) }\end{array}$ & $\begin{array}{l}\text { Planning cities with } \\
\text { utopian contects }\end{array}$ \\
\hline $\begin{array}{l}\text { Pendekatan } \\
\text { perencanaan }\end{array}$ & $\begin{array}{l}\text { Partisipatif - } \\
\text { community based } \\
\text { planning }\end{array}$ & $\begin{array}{l}\text { Panduan yang disusun } \\
\text { oleh perencana tanpa } \\
\text { memperhatikan } \\
\text { kebutuhan masyarakat } \\
\text { akan ruang }\end{array}$ \\
\hline $\begin{array}{l}\text { Outcomel } \\
\text { Impact } \\
\text { Effected }\end{array}$ & $\begin{array}{l}\text { Meciptakan kedekatan, } \\
\text { liveability dalam } \\
\text { perkotaan }\end{array}$ & $\begin{array}{l}\text { Menciptakan presisi, } \\
\text { menekankan pada } \\
\text { ketersediaan ruang di } \\
\text { masa mendatang }\end{array}$ \\
\hline Value & $\begin{array}{l}\text { Closeness, community, } \\
\text { personal beliefs and value }\end{array}$ & $\begin{array}{l}\text { Formal deduction and } \\
\text { planning development, } \\
\text { formal beliefs }\end{array}$ \\
\hline
\end{tabular}

\begin{tabular}{lll}
\hline Concept & Komunitas & Masyarakat Umum \\
\hline Bentukan fisik & Implikasi pada ruang & Implikasi pada ruang \\
kota & dengan blok - blok kecil, & dengan blok - blok besar, \\
& jalan - jalan yang & jalan - jalan yang lebar \\
& tidak terlalu lebar dan & dan, ketingian \\
& ruang kreatif, ketinggian & bangunan yang relatif \\
& bangunan yang relatif & tinggi dan guna lahan \\
& rendah dan guna lahan & yang cenderung single \\
& yang mixed use. & use.
\end{tabular}

Sumber: disarikan dari Jacobs (1992) dan Tonnies (1886)

Berdasarkan dari sintesa yang ada maka, dapat didefinisikan bahwa yang dinamakan sebagai gemeinschaft city atau Kota Guyub adalah: "merupakan kota atau area/bagian perkotaan yang memiliki karakter lokal dan nilai - nilai gemeinschaft yang diindikasikan oleh hubungan/ interaksi kekerabatan yang ada di wilayah tersebut dan terwujud dalam ekspresi keruangan yang intim dengan masyarakatnya”.

\section{B. Pengukuran Kota Guyub: Variabel, Indikator dan Bobot dalam Penelitian}

Dengan definisi yang sangat baru dari hasil sintesa antara Jacobs dan Tonnies, maka perlu sebuah indikator dan parameter untuk membuktikan apakah ada yang dinamakan dengan Kota Guyub. Setidaknya untuk membedakan bagaimana bentukan Kota Guyub dan Kota Formal maka ada tiga aspek yang harus ditilik, meliputi: bentuk dasar, underlying system dan ekspresi keruangan yang ditimbulkan.

Beberapa penelitian terbaru mengenai komunitas 'guyub' menunjukkan beberapa perkembangan, seperti sebuah kesimpulan bahwa tidak ada masyarakat yang benar - benar guyub ataupun benar - benar formal (Gram-Hanssen, K. 2000). Weber dalam, Waters (2015) menjelaskan bahwa masyarakat 'guyub' dan masyarakat formal akan terus menerus dalam sebuah tensi yang besar seperti air dan minyak dimana komposisinya tidak akan mengalami sebuah kepastian dan sangat bergantung pada situasi yang ada. "

Masyarakat gemeinschaft dibentuk berdasarkan dorongan naluri sehingga tidak ada aturan tertulis yang jelas sedangkan masyarakat gesselschaft dibentuk berdasarkan aturan yang tertulis dengan jelas sehingga setiap orang harus menjalankan peran masing - masing sesuai dengan aturan yang sudah dituliskan (Springborg, 1986). Pada aspek underlying system, komunitas yang bergerak di masyarakat gemeinschaft masih berlaku secara tradisional dimana komunitas tersebut masih bersifat sederhana dengan jenis aktivitas mayoritas masih homogen sedangkan pada masyarakat gesselschaft komunitas yang bergerak sudah mengarah pada organisasi modern dengan bentuk yang lebih kompleks dan kegiatan yang lebih heterogen. Nilai - nilai yang berlaku di masyarakat gemeinschaft juga masih didasarkan pada kepercayaan dan kedekatan interaksi sedangkan masyarakat gesselschaft didasarkan pada hukum- hukum tertulis yang berlaku. Hal-hal tersebut tentunya mengakibatkan perbedaan ekspresi keruangan (spasial) yang timbul dimana masyarakat gemeinschaft cenderung menimbulkan pola ruang perdesaan dengan blok-blok kecil dan bangunan rendah sedangkan masyarakat gesselschaft cenderung menimbulkan pola ruang kota-kota besar dengan bangunan tinggi. Perbandingan secara rinci perbedaan antara sistem guyub dan formal dapat dilihat pada Tabel 4 dan penjelasan lebih lanjut mengenai variabel dapat dilihat pada Tabel 5, sedangkan indikator per bobot dan variabel dapat dilihat pada Tabel 6 .

Tabel 4.

Komparasi Indikator - Variabel Penilaian Gemeinschaft City dengan Gesselschaft City

\begin{tabular}{|c|c|c|c|}
\hline Gemeinschaft & & & Gesselschaft \\
\hline \multicolumn{4}{|c|}{ Basic Form/Concept } \\
\hline \multirow[t]{3}{*}{ Wessenwille } & $\begin{array}{l}\text { Communal } \\
\text { will/concensuss }\end{array}$ & $\begin{array}{l}\text { Social } \\
\text { contract/law and } \\
\text { contract }\end{array}$ & Kurwille \\
\hline & $\begin{array}{l}\text { Organic/spontane } \\
\text { ous }\end{array}$ & $\begin{array}{l}\text { Future } \\
\text { oriented/calculate } \\
d\end{array}$ & \\
\hline & instinctive & Rational will & \\
\hline \multicolumn{4}{|c|}{$\begin{array}{l}\text { Underlying System } \\
\end{array}$} \\
\hline \multirow[t]{2}{*}{$\begin{array}{l}\text { Traditional } \\
\text { Community }\end{array}$} & $\begin{array}{l}\text { Simple } \\
\text { organization }\end{array}$ & $\begin{array}{l}\text { Complex } \\
\text { organization }\end{array}$ & Modern Society \\
\hline & $\begin{array}{l}\text { Homogenous } \\
\text { activity }\end{array}$ & $\begin{array}{l}\text { Heterogenous } \\
\text { activity }\end{array}$ & \\
\hline
\end{tabular}




\begin{tabular}{|c|c|c|c|}
\hline & $\begin{array}{l}\text { Homogenous } \\
\text { concern/problem }\end{array}$ & $\begin{array}{l}\text { Heterogeous } \\
\text { concern/problem }\end{array}$ & \\
\hline \multirow{3}{*}{$\begin{array}{l}\text { Value } \\
\text { Beliefs }\end{array}$} & Trust & Law & \multirow{3}{*}{$\begin{array}{l}\text { Interdependent } \\
\text { system }\end{array}$} \\
\hline & Close interaction & $\begin{array}{l}\text { Formal } \\
\text { interaction }\end{array}$ & \\
\hline & $\begin{array}{l}\text { Community } \\
\text { initiative }\end{array}$ & $\begin{array}{l}\text { Government } \\
\text { initiative }\end{array}$ & \\
\hline \multicolumn{4}{|c|}{ Planning System and Embodied } \\
\hline \multirow[t]{2}{*}{$\begin{array}{l}\text { Participatory } \\
\text { Planning }\end{array}$} & $\begin{array}{l}\text { Collaboration in } \\
\text { development }\end{array}$ & $\begin{array}{l}\text { Government } \\
\text { control }\end{array}$ & \multirow{2}{*}{$\begin{array}{l}\text { Comprehensivel } \\
\text { Rational } \\
\text { Planning }\end{array}$} \\
\hline & $\begin{array}{l}\text { High level of } \\
\text { participation }\end{array}$ & $\begin{array}{l}\text { Low - moderate } \\
\text { level of } \\
\text { participatory }\end{array}$ & \\
\hline $\begin{array}{l}\text { Liveability } \\
\text { orientation }\end{array}$ & $\begin{array}{l}\text { High perception } \\
\text { on liveability }\end{array}$ & $\begin{array}{l}\text { Low preception } \\
\text { on liveability }\end{array}$ & $\begin{array}{l}\text { Precission } \\
\text { orientation }\end{array}$ \\
\hline \multirow{7}{*}{$\begin{array}{l}\text { Physical } \\
\text { Embodied: } \\
\text { Town }\end{array}$} & Village/towm & $\begin{array}{l}\text { Metropolis/megac } \\
\text { ities }\end{array}$ & \multirow{7}{*}{$\begin{array}{l}\text { Physical } \\
\text { Embodied: } \\
\text { Megacities }\end{array}$} \\
\hline & Mixed use & Single use & \\
\hline & Small block & Mega block & \\
\hline & $\begin{array}{l}\text { More street and } \\
\text { intersection }\end{array}$ & $\begin{array}{l}\text { Less street and } \\
\text { intersection }\end{array}$ & \\
\hline & $\begin{array}{l}\text { Low to moderate } \\
\text { building }\end{array}$ & $\begin{array}{l}\text { Moderate to high } \\
\text { building }\end{array}$ & \\
\hline & Civic centre & Less civic centre & \\
\hline & $\begin{array}{l}\text { Highly creative } \\
\text { space }\end{array}$ & $\begin{array}{l}\text { Low } \\
\text { space }\end{array}$ & \\
\hline
\end{tabular}

\begin{tabular}{|c|c|c|}
\hline & Interaction & $\begin{array}{l}\text { Banyaknya interaksi yang berjalan dalam } \\
\text { kehidupan bertetangga }\end{array}$ \\
\hline 4 & \multicolumn{2}{|c|}{$\begin{array}{l}\text { Liveability Orientation: persepsi terhadap tingkat kenyamanan hidup } \\
\text { di masyarakat }\end{array}$} \\
\hline$a$ & $\begin{array}{l}\text { Perception on their } \\
\text { liveability }\end{array}$ & $\begin{array}{l}\text { Pandangan tingkat kenyamanan hidup } \\
\text { masyarakat }\end{array}$ \\
\hline & \multicolumn{2}{|c|}{$\begin{array}{l}\text { Participatory Planning: bentuk partisipasi pembangunan yang } \\
\text { dilakukan masyarakat }\end{array}$} \\
\hline & Level of participation & $\begin{array}{l}\text { Pada masyarakat tradsional, seharusnya tingkat } \\
\text { partisipasi masyarakat relatif lebih } \\
\text { tinggi dibandingkan dengan masyarakat } \\
\text { modern }\end{array}$ \\
\hline & $\begin{array}{l}\text { Collaboration in } \\
\text { development/governm } \\
\text { ent control }\end{array}$ & $\begin{array}{l}\text { Adanya kelompok masyarakat yang aktif dan } \\
\text { turut serta selama proses pembangunan } \\
\text { (pembangunan tidak hanya menjadi tugas } \\
\text { pemerintah) } \\
\text { Sebaliknya, pihak pemerintah juga melbatkan } \\
\text { masyarakat dalam pembangunan }\end{array}$ \\
\hline
\end{tabular}

6. Physical Embodied: ciri atau perwujudan fisik dari gejala - gejala keruangan yang ada di wilayah tersebut akibat terbentuknya gemeinschaft

a. Ability to create Jumlah terciptanya ruang-ruang kreatif, ruang creative space (space kreatif bisa jadi merupakan ruangan untuk that grow based on berkespresi dan sesuatu yang timbul karena community initiative) inisiasi dan kebtuhan masyarakat

b. Mixed use Dengan adanya konsekunsi tata guna lahan yang mixed use dan berdasarkan penelitian penelitian yang ada, semakin banyak ruang publik (dalam hal ini termasuk jalan) maka semakin memungkinkan terbentuknya ruang kreatif dan berfungsi sebagai civic centre

Tabel 5.

Indikator - Variabel Penilaian Kota Guyub Indikator/Variabel Keterangan

1. Wessenwille: motivasi bergerak. Terdapat suatu aktivitas pergerakan dalam masyarakat baik secara terencana-teratur maupun secara tidak terencana-sesekali. Kota dengan ciri guyub memiliki motivasi yang bersifat spontan dan disebut wessenwille \begin{tabular}{lll}
\hline$a$. & Concencuss & $\begin{array}{l}\text { Masyarakat memiliki kegiatan forum - forum } \\
\text { yang diadakan secara rutin untuk }\end{array}$
\end{tabular} menyepakati bersama pembangunan yang dilakukan di wilayah tersebut \begin{tabular}{lll}
\hline b. Organic & $\begin{array}{l}\text { Pola pertumbuhan wilayah berasal dari inisiasi } \\
\text { masyarakat itu sendiri yang berasal dari inisiasi }\end{array}$
\end{tabular} masyarakat

c. Instictive will Masyarakat melakukan penyelesaian masalah di lingkungannya karena dorongan secara naluri, seringkali mengakibatkan sebuah perspektif tambal sulam dalam penyelesaian masalah

2. Traditional Community: adanya kelompok-kelompok masyarakat yang memiliki ciri-ciri tradisional/sederhana

a. Occupation Ciri masyarakat yang sederhana biasanya

homogenity memiliki kesamaan jenis pekerjaan seperti bertani, nelayan ataupun pekerjaan yang lain

b. Institution on society Keberadaan lembaga dalam kelompok masyarakat ini menunjukkan tingkat kemapanan dalam masyarakat, namun semakin komplek kelembagaan yang ada biasanya masyarakat sudah meninggalkan ciri gemeinschaft dan menuju masyarakat yang formal

\begin{tabular}{ll}
\hline c. Mutual activities & $\begin{array}{l}\text { Banyaknya kesamaan aktivitas yang dimiliki } \\
\text { oleh masyarakat sebagai ciri khas dari } \\
\text { masyarakat tradisional }\end{array}$ \\
\hline $\begin{array}{l}\text { d. } \text { Mutual } \\
\text { concern/problem }\end{array}$ & $\begin{array}{l}\text { Adanya permasalahan yang menjadi perhatian } \\
\text { bersama di masyarakat }\end{array}$ \\
\hline
\end{tabular}

3. Value and Beliefs: nilai/nroma/kepercayaan yang berlaku di masyarakat

\begin{tabular}{lll}
\hline a. & Closeness (guyub) & Tingkat kedekatan antar warga \\
\hline b. & Trust & Tingkat kepercayaan satu sama lain \\
& (kepercayaan) & dalam kehidupan bertetangga \\
\hline
\end{tabular}

c. $\quad$ Street \& Intersection

Dengan adanya konsekunsi tata guna lahan yang mixed use dan berdasarkan penelitian penelitian yang ada, semakin banyak ruang publik (dalam hal ini termasuk jalan) maka semakin memungkinkan terbentuknya ruang kreatif dan berfungsi sebagai civic centre

d. Building height Jumlah bangunan tinggi di lingkungan masyarakat, dengan asumsi semakin banyak bangunan tinggi maka, semakin mewujud menjadi masyarakat modern

Sumber: Hasil Analisis, 2018

Tabel 6.

Bobot Penilaian Indikator - Variabel Gemeinschaft City - Gesselschaft City

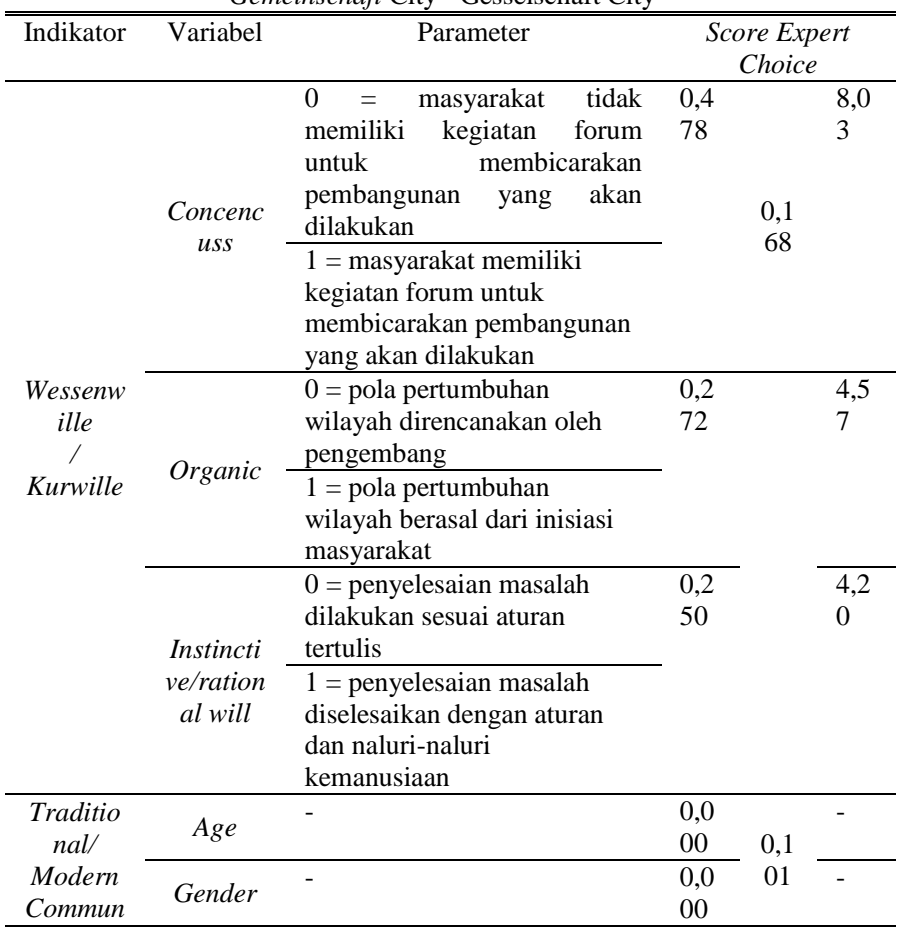




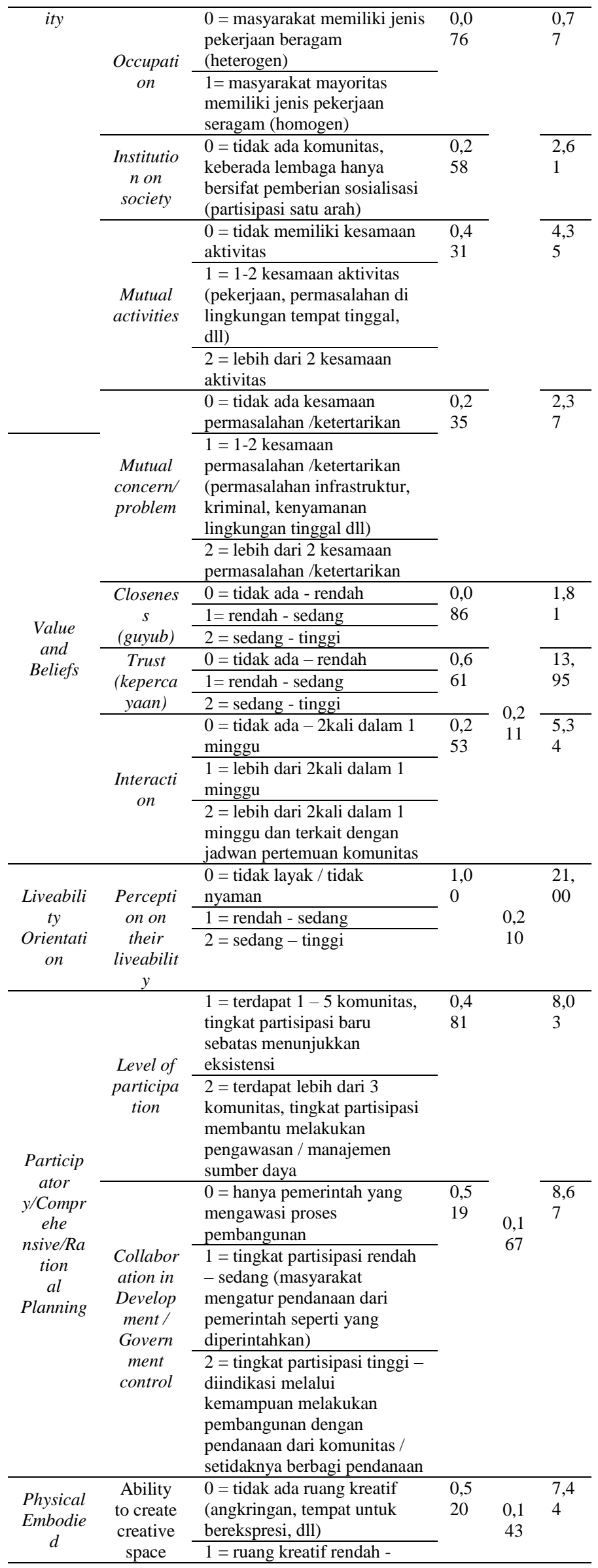

\begin{tabular}{|c|c|c|c|}
\hline $\begin{array}{l}\text { (space } \\
\text { that } \\
\text { grow } \\
\text { based on }\end{array}$ & $\begin{array}{l}\text { sedang } \\
2=\text { ruang kreatif tinggi } \\
\text { (public space and place }\end{array}$ & & \\
\hline \multirow[b]{2}{*}{$\begin{array}{c}\text { Mixed } \\
\text { use }\end{array}$} & $\begin{array}{l}0=\text { penggunaan lahan tunggal } \\
(1 \text { fungsi) }\end{array}$ & \multirow[t]{2}{*}{$\begin{array}{l}0,2 \\
08\end{array}$} & \multirow[t]{2}{*}{$\begin{array}{l}2,9 \\
7\end{array}$} \\
\hline & $\begin{array}{l}1=\text { tingkat penggunaan lahan } \\
\text { campuran sedang } \\
2=\text { tingkat penggunaan lahan } \\
\text { campuran tinggi }\end{array}$ & & \\
\hline \multirow{2}{*}{$\begin{array}{l}\text { Street \& } \\
\text { Intersect } \\
\quad \text { ion }\end{array}$} & $\begin{array}{l}0=\text { jalan dan persimpangan } \\
\text { rendah }\end{array}$ & \multirow[t]{2}{*}{$\begin{array}{l}0,1 \\
68\end{array}$} & \multirow[t]{2}{*}{$\begin{array}{l}2,4 \\
0\end{array}$} \\
\hline & $\begin{array}{l}1=\text { jalan dan persimpangan } \\
\text { padat }\end{array}$ & & \\
\hline $\begin{array}{c}\text { Building } \\
\text { height }\end{array}$ & $\begin{array}{l}0=\text { tinggi bangunan sedang - } \\
\text { tinggi }\end{array}$ & $\begin{array}{l}0,1 \\
04\end{array}$ & $\begin{array}{l}1,4 \\
9\end{array}$ \\
\hline
\end{tabular}

IV. KESIMPULAN

Kota yang Guyub memang masih menjadi sebuah wacana dimana keberhasilan atau keterkaitan pada keberhasilan perencanaan baik fisik non fisik belum teruji dengan baik, sehingga selanjutnya penelitian ini dapat melanjutkan publikasinya mengenai laporan etnografi yang dihasilkan terhadap studi - studi kasus yang ada.

\section{DAFTAR PUSTAKA}

[1] Al-Kodmany, K. (2001). Bridging the gap between technical and local knowledge: Tools for promoting community-based planning and design. Journal of Architectural and Planning research, 110-130.

[2] Gram-Hanssen, K. (2000). Local agenda 21. Traditional Gemeinschaft or late-modern subpolitics? Journal of Environmental Policy and Planning, 2(3), 225-235.

[3] Grengs, J. (2002). Community-based planning as a source of political change: The transit equity movement of Los Angeles' Bus Riders Union. Journal of the American Planning Association, 68(2), 165-178.

[4] Jacobs, Jane. (1992) The death and life of great American cities /New York : Vintage Books,

[5] Lefebvre, Henri,. (1991). The Production of Space, Blackwell

[6] Mason, D. R., \& Beard, V. A. (2008). Community-based planning and poverty alleviation in Oaxaca, Mexico. Journal of Planning Education and Research, 27(3), 245-260.

[7] Springborg, P. (1986). Politics, primordialism, and orientalism: Marx, Aristotle, and the myth of the Gemeinschaft. American Political Science Review, 80(1), 185-211.

[8] Tönnies, Ferdinand (1886). Gemeinschaft und Gesellschaft, Leipzig: Fues's Verlag. An English translation of the 8th edition 1935 by Charles P. Loomis appeared in 1940 as Fundamental Concepts of Sociology (Gemeinschaft und Gesellschaft), New York: American Book Co.; in 1955 as Community and Association (Gemeinschaft und gesellschaft[sic]), London: Routledge \& Kegan Paul

[9] Waters, Tony (2015). Encyclopedia of Sociology, $2^{\text {nd }} e d ., 2015$. California State University

[10] Walker, J., Mitchell, B., \& Wismer, S. (2001). Livelihood strategy approach to community-based planning and assessment: a case study of Molas, Indonesia. Impact assessment and project appraisal, 19(4), 297309. 